Ika Nurul Qamari', Leli J oko Suryono

1Prodi M anajemen, Fakultas Ekonomi, U niversitas M uhammadiyah Yogyakarta 2Prodi IImu H ukum, Fakultas H ukum, U niversitas M uhammadiyah Yogyakarta Jalan Brawijaya, Tamantirto, Kasihan, Bantul, Yogyakarta, 55183 1Email: ika_nr@umy.ac.id

\title{
Peningkatan Kualitas Layanan Dan Tata Kelola Pendidikan Anak Usia Dini Kenanga Panggung Harjo, Sewon, Bantul
}

https:/ / doi.org/ 10.18196/ bdr.5226

\begin{abstract}
ABSTRAK
Keberadaan Pendidikan Anak Usia Dini (PAUD) menurut Peraturan Menteri Pendidikan Nomor 13 Tahun 2005 merupakan jenis pendidikan non formal. Penyelenggaraan PAUD utamanya ditujukan untuk pendidikan pra sekolah, yaitu untuk anak-anak usia dini (0 - 6 tahun). PAUD Kenanga dalam penyelenggaraannya telah mengalami berbagai perubahan pengelola, dimana pada mulanya diselenggarakan menurut keberadaan Posyandu (Pos Pelayanan Terpadu) untuk kesehatan ibu dan anak di setiap dusun (Pedukuhan Glugo ada 4 dusun). Tujuan program ini adalah meningkatkan kualitas layanan penyelenggaraan PAUD dan perbaikan tata kelola (manajemen) baik dari sisi struktur pengelolaan maupun administrasi PAUD. Metode pendekatan partisipatif dengan focus group discussiondilaksanakan dengan melibatkan kelompok ibu-ibu PKK (Pemberdayaan dan Kesejahteraan Keluarga), Kepala Pedukuhan Glugo, dan ibu-ibu sukarelawan yang selalu siap sedia melaksanakan kegiatan PAUD. Hasil dan Implikasi meliputi terpadunya penyelenggaraan PAUD di Pedukuhan Glugo, yang sebelumnya diselenggarakan di setiap dusun, saat ini telah terpadu menjadi satu, yakni Satuan PAUD Sejenis Kenanga. Kualitas layanan juga meningkat, dengan terpadunya tata kelola di tingkat pedukuhan. Beberapa peningkatan kualitas layanan yang terlaksana adalah dibangunnya ruang bermain dan belajar, pembelian dan pengadaan alat-alat bermain indoor dan outdoor, pengadaan seragam untuk peserta didik, pengadaan seragam untuk pengelola dan pendidik, penyelenggaraan rekreasi untuk ibu dan anak, mendatangkan guru menyanyi dan pengenalan musik.

Kata Kunci: pendidikan anak usia dini, kenanga, kualitas layanan, tata kelola
\end{abstract}

\section{PENDAHULUAN}

U sia dini merupakan masa tahapan awal kehidupan manusia, dimana pada tahap ini adalah masa yang tepat untuk mengenalkan dasar-dasar pen gembangan kemampuan fisik (koordinasi motorik halus dan kasar), perkembangan intelegensi (daya pikir, daya cipta), kecerdasan (kecerdasan emosi, kecerdasan spiritual), sosio emosional (sikap dan perilaku serta nilai-nilai agama), bahasa dan komunikasi sesuai dengan keunikan serta tahapan yang dilalui oleh setiap anak usia dini (Seniati, 2013). Kemajuan negara akan semakin kuat apabila semua elemen masyarakat berkontribusi,salah satunya adalah bagaimana 
mempersiapkan anak-anak usia dini untuk belajar den gan lingkungannya. Generasi bangsa dipersiapkan sejak masa anak-anak di usia dini agar lebih mudah menyesuaikan diri dengan lingkungan belajar di bangku pendidikan formal. U N ESC 0 telah mencanagkan bahwa setiap anak usia dini mendapatkan pendidikan pada usia pra sekolah.

Lingkungan belajar di sekolahtentu berbeda dengan lingkungan di rumah.Dengan adanya PAU D bisa menjembatani perbedaan suasana di kedua tempat tersebut. A nakanak usia dini akan belajar berinteraksi dengan anak yang sebayanya, diperkenalkan dengan beberapa aturan yang ditetapkan PAU D, belajar beradaptasi dengan lingkungan, dan sebagainya. Anak yang sebelumnya mendapatkan pendidikan di PAUD akan memiliki kemampuan yanglebih baik dalam berkomunikasi dan beradaptasi saat memasuki jenjang sekolah formal. Hal ini dikarenakan anak sudah terbiasa untuk bermain, belajar, hingga makan bersama dengan teman yang memiliki usia sebaya.

PAUD Kenanga telah berdiri sejak 2009 dengan kesukarelaan ibu-ibu PKK di lingkungan D usun Janganan, Panggungharjo, Sewon, Bantul. Sepanjang perjalanannya para penggiat PAU D mengalami kendala, dimana pengajar PAUD silih berganti, dan semakin lama berkurang.U ntuk menjaga keberlanjutan, efektivitas, dan efisiensi penyelenggaraan PAU D, disepakati oleh para pengel ola PAU D di 4 pedusunan Pedukuhan Glugountuk menjadikan satu lembaga, dengan nama Satuan PAUD Sejenis (SPS) "Kenanga".Awal mula penyelenggaraan PAU D menjadi satu dengan pengelolaan POSYANDU di setiap dusun, dengan nama Kenanga 1, Kenanga 2, Kenanga 3, dan Kenanga 4. D engan kesepakatan ibu-ibu PKK di wilayah pedukuhan Glugo, disepakati penggabungan PAUD Kenanga, sehingga kepengelolaan terpisah dengan pengelola POSYANDU.

Selanjutnya dilakukan pengupayaan Akte Notaris, dimana pengurus inti memohon kepada PPAT W idiyantara, S.H ., M .Kn., sehingga keluarlah A kte Notaris dengan No.9 tanggal 14 Februari 2012.Pengajuan ijin operasional juga berhasil diupayakan dengan N o.012/ SPS/ III/ 2014 dikeluarkan tanggal 17 M aret 2014, dan telah diperpanjang dengan N o.012/ SPS/ III/ 2016.D engan adanya akte notaris dan ijin operasional maka SPS Kenanga memberanikan diri seperti lembaga PAU D lainnya untuk mengajukan Bantuan O perasional PAUD.

Bantuan O perasional PAUD (BOP) bertujuan untuk meningkatkan layanan PAUD berkualitas dalam bentuk Taman Kanak-Kanak, Kelompok Bermain, Taman Penitipan Anak, dan Satuan PAU D Sejenis di seluruh Kabupaten/Kota di Indonesia. Sasaran program BOP PAUD adalah bentuk Taman Kanak-Kanak, Kelompok Bermain, Taman 
Penitipan Anak, dan Satuan PAUD Sejenis di seluruh Kabupaten/Kota di Indonesia yang diselenggarakan oleh individu, kelompok, yayasan, organisasi maupun Pemerintah Daerah di satuan PAUD atau Lembaga, satuan pendidikan PKBM, SKB, badan keagamaan, dan satuan pendidikan non formal lainnya yang sudah memiliki Nomor Pokok Satuan PAU D Nasional (NPSN).

Sampai sejauh ini pengelola telah mengupayakan prosedur perizinan, akte notaris, nomor pokok sekolah nasional. Namunpenataan ruang belajar dantata letak atau layout pembelajaran, dan terbatasnya jumlah tenaga pen gel ola dan tenaga pendidik, terbatasnya ketersediaan dan kualitaslayan an PAU D, keterbatasan sumberdaya finansial PAU D masih menjadi perhatian untuk pengingkatan kualitas layanan dan tata kelola PAU D.

D isamping itu mengalamisistem administrasi dan pembukuan yangdicatat masih secara manual. Untuk memberikan peningkatan kualitas pelayanan dan administrasi yang memadai, maka perlu adanya komputerisasi administrasi dan pembukuan serta pengembangan bagi pengelola dan pendidik PAU D.

Berdasarkan analisis situasi dan hasil survey lapangan, permasalahan yang diangkat pada program ini antara lain:

1. Terbatasnya kualitas sumberdaya manusia seperti keterampilan SD M, kurangnyajiwa kewirausahaan, gagap teknologi dan manajemen;

2. Jumlah Pengelola dan Pendidik yang belum memadai, masih terbatasnya sarana pembelajaran, terbatasnya ketersediaan dan kualitas layanan PAUD, keterbatasan sumberdaya finansial, serta sistem administrasi dan pembukuan masih secara manual.

Tujuan dari pengabdian masyarakat ini adalah: a) meningkatkan kualitas layanan penyelenggaraan PAU D ; b) meningkatkan ketrampilan pengelola dan pendidik PAUD; c) meningkatkan kualitas layanan administrasi dan pembukuan; d) meningkatkan tata kelola PAU D

\section{TINJAUAN PUSTAKA}

Pendidikan anak usia dini merupakan aset penting bangsa Indonesia, sehingga perlu mendapat perhatian khusus supaya tercipta generasi bangsa yang berkualitas. Lingkup pembelajaran PAUD mencakup kompetensi dasar yang memadukan semua program pengembangan yaitu nilai agama dan moral, fisik-motorik, kognitif, bahasa, sosialemosional, dan seni (C atur RW, 2015). Beberapa hal penting yang perlu dilakukan untuk anak usia dini adalah: 


\section{9}

a. Membiasakan anak terhadap kegiatan terstruktur

Kelembagaan PAUD memang bukan lembaga pendidikan formal, namunkegiatan yang diselenggarakan, baik pada playgroup atau TK didesain khusus agar sesuai dengan fungsi pendidikan anak usia dini. Tujuan utama penyelenggaraan PAU D adalah melatih agar anak terbiasa terhadap rutinitas dan kegiatan kegiatanterstruktur serta mengenalkan kemandirian sejak dini. M isalnya, anak akan belajar berdoa, bermain di lingkungan outdoor (tentunya dengan pendampingan), beradaptasi, berbaris (melatih disiplin), berbagi dengan teman (saat bermain indoor), dan sebagainya (H aryati, 2012).
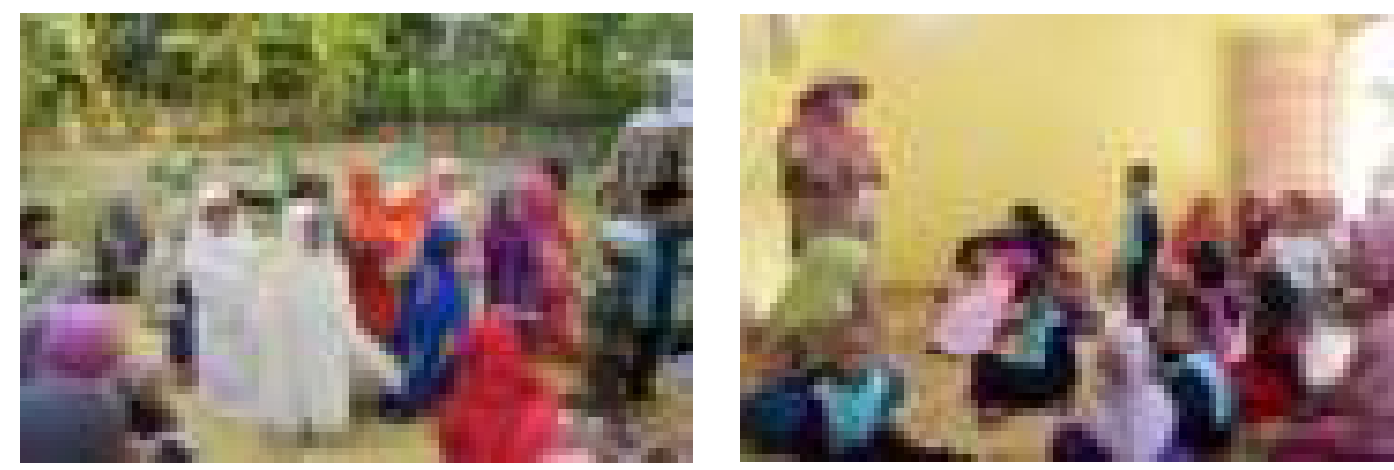

Gambar 1. K egiatan 0 utdoor, Sholat

PAU D K enanga, Panggungharjo, Sewon, Bantul

G ambar 2. K egiatan Indoor, C erita C aping PAU D K enanga, Panggungharjo, Sewon, Bantul

\section{b. Mengajarianak supaya disiplin dan mengikuti peraturan}

Setiap orang tua tentunya mengupayakan agar anak tumbuh dan berkembang secara sehat. A pabila di rumah, si anak tentu terbiasa bermain sesuka hati. la juga mungkin sudah terbiasa mengi kuti "aturan" yang ditetapkan oleh ibunya, yang biasanya tergolong longgar atau lentur dibandingkan "aturan" yang terdapat di luar rumah. Sehingga, pada usia pra sekolah adalah saat yang tepat bagi si anak untuk belajar mengikuti pola kegiatan maupun aturan lain di luar rumah. M engikuti kegiatan pendidikan anak usia dini akan melatih si anak beradaptasi dengan lingkungan baru dan peraturan baru. Anak juga akan belajar berbagi, mengantri dengan berbaris rapi, menunggu, dan memahami bahwa ternyata tidak semua hal yang diinginkan bisa diperoleh dengan mudah. Dengan demikian, anak tidak akan kaget atau stres saat masuk SD dan harus belajar dalam situasi yang sangat terstruktur dan menuntut kedisiplinan. 
c. Menumbuhkan imajinasi dan kreativitas

Anak usia dini belajar dengan cara bermain. Berbagai lembaga penyedia pendidikan anak usia dini merupakan tempat yang tepat untuk memfasilitasi kebutuhan si anak. Bila si anak belajar dalam suasana yang menyenangkan, akan lebih mudah baginya untuk menyerap berbagai bimbingan yang diberikan. Selain mempelajari berbagai keterampilan dasar untuk mengenal berbagai benda dan lingkungan di sekitar anak, si anak juga akan mendapatkan banyak rangsangan yang akan memancing imajinasi dan kreativitasnya.

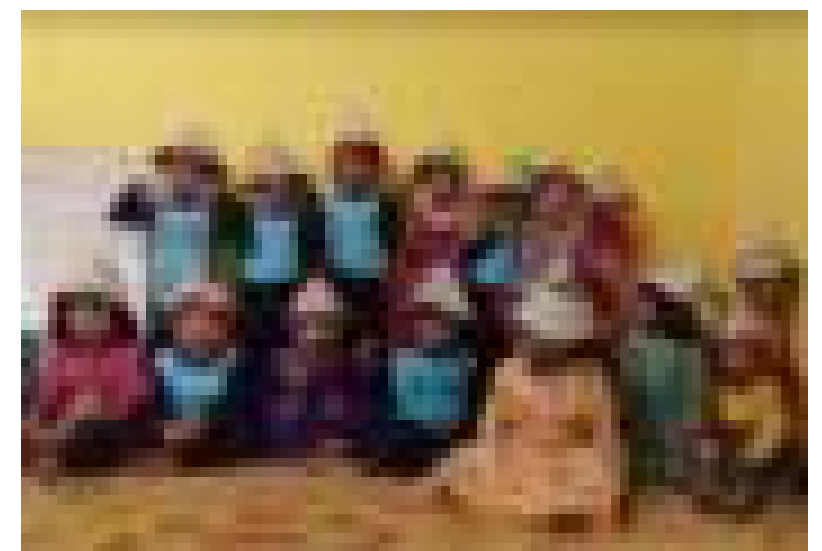

Gambar 3. Membuat Caping dari Kertas Koran PAUD Kenanga, Panggungharjo, Sewon, Bantul

\section{d. Menanamkan nilai-nilai positif}

Program kegiatan yang diadakan oleh berbagai lembaga pendidikan anak usia dini juga bertujuan menanamkan nilai-nilai positif, seperti kejujuran, toleransi, berbagi, dan sebagainya. Pada usia pra sekolah, anak belajar dengan cara bermain. O leh karena itu, kegiatan yang dilakukan di playgroup dan TK dirancang layaknya permainan, walaupun sebenarnya menyimpan maksud pembelajaran tertentu. M elalui berbagai permainan, si anak belajar mengenai sopan santun, menghormati orang lain, berbagi dengan temantemannya, pentingnya bersikap jujur, dan sebagainya.

\section{e. Membentuk dasar kepribadian anak}

Pada masa keemasan (golden years), otak anak mengalami perkembangan yang san gat pesat. Pengalaman si anak pada periode ini turut membentuk kepribadiannya dan akan mempengaruhi karakternya hingga kelak ia dewasa. Sehingga pendidikan karakter memang sebaiknya dimulai sejak dini. Dengan program pendidikan anak usia dini, si anak akan mendapatkan berbagai keteladanan dan kegiatan positif yang akan diingat dan dipraktikkan dalam kehidupannya (W idodo, 2011). 


\section{1}

D engan mempertimbangkan manfaat penting inilah perlu sosialisasi gencar kepada para ibu yang mempunyai anak usia dini agar lebih paham bahwa mendaftarkan dan mendampingi si anak ke PAU D memberikan banyak manfaat. Sekali waktu diupayakan ada kegiatan parenting bagi para ibu-ibu untuk memastikan bahwa pembelajaran yang diselenggarakan PAU D selaras dengan yang diajarkan oleh para ibu anak-anak PAUD saat di rumah. Hal ini perlu dilakukan sebab, meski pendidikan anak usia dini berpengaruh penting bagi perkembangan si anak. Kegiatan tahunan lainnya yang melibatkan orang tua adalah kegiatan piknik dan syawalan yang juga dimanfaatkan mengundang peserta baru untuk masyarakat pedukuhan G lugo. Namun, peran ibu dan ayah sebagai pendidik utama bagi anak tetap tak dapat tergantikan. O leh karenanya, para pengelola perlu men gidentifikasi setiap peserta dan tempat tinggalnya, yang sekali waktu bersilaturahmi ke rumah peserta didik, agar mengenal satu per satu keluarga dari si anak.

\section{METODE PELAKSANAAN}

Permasalahan yang dihadapi akan dicoba dicarikan pemecahannya dengan melakukan penyuluhan, pelatihan dan pendampingan penyelenggaraan PAUD. M etode yang digunakan untuk menyelesaikan permasalahan tersebut melalui tahapan sebagai berikut: a. M elaksanakan focus group discussion tentang penyelenggaraan PAUD saat ini, identifikasi kendala dan permasalahan. Kegiatan ini melibatkan ibu-ibu PKK Glugo dan Kepala Pedukuhan G lugo. Hal ini perlu dilaksanakan, karena keberadaan PAU D di bawah koordinasi Bapak Dukuh dan Ketua PKK Glugo Panggungharjo Sewon Bantul.

b. Mengirimkan baik pengelola maupun pendidik pada program peningkatan ketrampilan yang diselenggarakan oleh Dinas Pendidikan Menengah dan Non Formal.

c. Pendampingan dalam administrasi dan pembukuan dengan komputerisasi

d. Pendampingan penyusunan BOP PAUD.

\section{HASIL DAN PEMBAHASAN}

Seperti disampaikan pada awal tulisan ini, bahwa dengan partisipasi dan kontribusi berbagai pihak, baik dari Kepala D ukuh, Ketua PKK Pedukuhan, ibu-ibu penggiat PKK dan ibu-ibu sukarelawan yang telah meluangkan baik waktu, biaya dan energi maka kualitas layanan dan tata kelola PAU D yang terpadu tercapai. Terpadunya penyelenggaran 
PAU D di pedukuhan Glugo, menjadikan program penyelenggaraan PAU D lebih terarah, efektif dan efisien. Dari segi pengelola, hal ini menjadikan lebih mudah dalam memperoleh peserta didik, pengajuan dana operasional yang lebih efektif, pengembangan program PAU D lebih terarah dan efisien.

Untuk meningkatkan ketrampilan pengelola dan pendidik, setiap kali ada kegiatan seminar atau workshop selalu mengirimkan utusan, baik yang diselenggarakan oleh T im Diklat Kabupaten Bantul atau Dinas Pendidikan M enengah dan Non Formal.

Keberadaan PAUD Kenanga sampai sejauh ini bisa diilustrasikan sebagai berikut:

Nama Lembaga

Alamat Lembaga

NPSN

Nomor Telpun / HP

Nama Ketua Pengelola

Tahun Pendirian

Akte Notaris oleh

NPWP

Ijin Operasional

Nama Bank

Program Layanan

Pertemuan 1 Minggu

J umlah Pendidik Pendidikan Pendidik J umlah Pengelola

Pendidikan Pengelola J umlah Peserta Didik

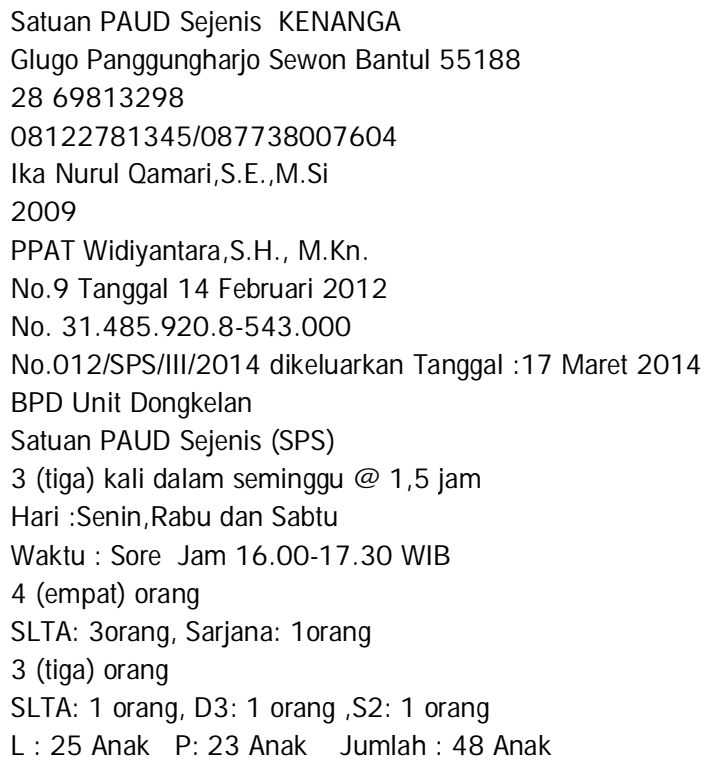

Pendampingan dalam pembuatan pengajuan proposal tiap tahun masih dilakukan, hal ini dikarenakan hampir setiap tahun ada format baru, sehingga perlu ada penyamaan persepsi untuk pengajuan proposal. Namun, karena hampir tiap tahun format dari D inas Pendidikan Pemuda dan O lah Raga sudah semakin bagus, lama-lama kesekretariatan PAUD Kenanga sudah terbiasa, sehingga diharapkan ke depan bisa mandiri. Komputerisasi administrasi dan pembukuan sampai sejauh ini masih menggunakan peralatan pribadi pengelola PAU D. Sampai sejauh ini baik pihak kesekretariatan dan pengelola belum mengalami kendala berarti, namun ke depan perlu adanya sarana kesekretariatan yang lebih baik. 


\section{3}

Sebagai wujud bahwa keberadaan PAU D terselenggara den gan baik, maka diupayakan papan nama PAU D. Seperti diilustrasikan pada G ambar 5 papan nama PAU D Kenanga telah terpasang di halaman depan.

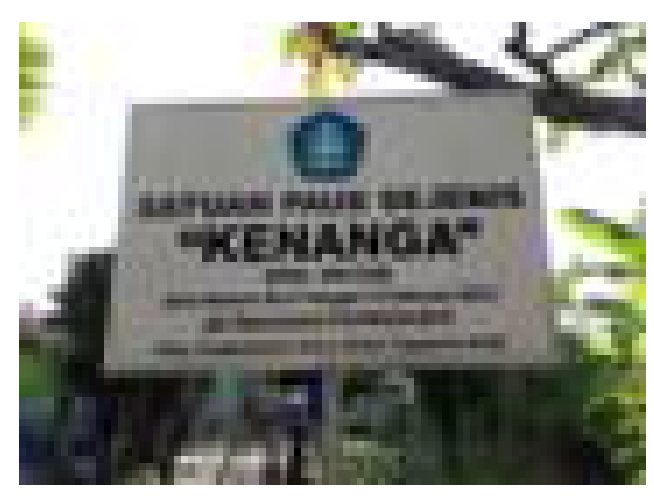

Gambar 5. Papan Nama PAUD Kenanga

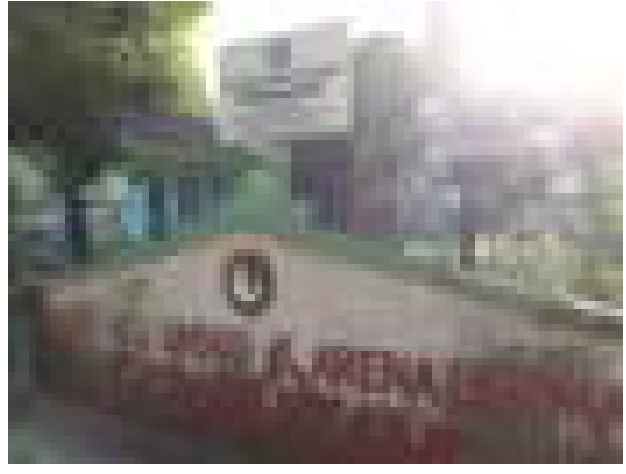

Gambar 6. Halaman PAUD Kenanga

Tempat penyelenggaraan PAUD Kenangamasih dalam satuhalamandengan Taman Kanak-Kanak (TK)Budi U tami Pedukuhan G lugo, Panggungharjo Sewon Bantul.Ruang belajar yang ada masih berbagi dengan TK Budi U tami, dimana pagi hari digunakan untuk TK Budi U tami, sore hari dimanfaatkan oleh PAUD Kenanga.

\section{Makna Eksistensi Satuan PAUD Sejenis Kenanga ter hadap Lingkungannya}

PAU D Kenanga merupakan lembaga pendukung kegiatan pemerintah, dalam hal ini D inas Pendidikan M enengah dan N on Formal di D usun Janganan Panggungharjo Sewon Bantul. Sejak awal berdiri, segala operasional kegiatan adalah atas kesukarelaan ibu-ibu PKK. Namun dalam perjalanannya perlu peningkatan gizi anak dan peralatan belajar mengajar, sehingga dalam perjalanannya disepakati untuk diadakan infaq yang harus dibayarkan oleh orang tua dari anak didik PAU D Kenanga. Dengan adanya perhartian dari Dinas Pemberdayaan Masyarakat D esa, setiap tahun memberi kontribusi untuk peningkatan pemberian makanan tambahan untuk anak-anak PAUD. Sehingga setiap penyelenggaraan PAU D, peserta didik mendapat makanan tambahan berupa susu, sayursayuran, buah-buahan, karbohidrat dan protein yang diberikan setelah proses belajar dan bermain selesai, yang menunya dikombinasi supaya anak-anak PAUD merasa suka dan senang untuk mengkonsumsi sajian yang telah disediakan. Tentunya hal ini melibatkan orang tua/ wali murid yang turut mendampingi selama proses belajar dan bermain. 
Kegiatan PAUD Kenanga disambut antusias oleh ibu-ibu yang memiliki anak di bawah usia lima tahun (Balita). Ibuibu di Pedukuhan Glugo ikut berpartisipasi untuk semaraknya penyelenggaraan PAU D dengan mengantar anaknya masing-masing, serta berperan aktif dalam proses pembelajaran anak-anak balita dan mendampingi saat jam bermain. Sehingga dari sejak berdiri hingga

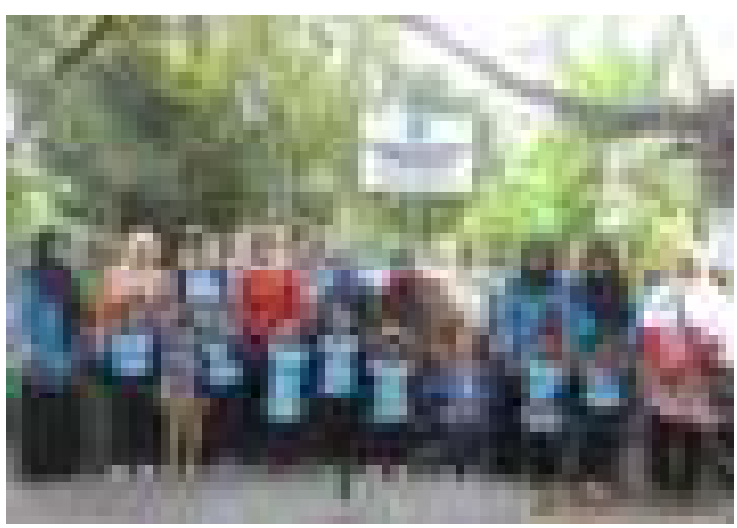

Gambar 7. Peserta PAUD Kenanga dengan Orang Tua/Wali Murid dan Ibu Guru sekarang keberadaan SPS Kenanga berjalan baik dan meningkatnya jumlah peserta PAU D dari tahun ke tahun.

Dengan adanya Program BO P oleh Dinas Pendidikan Menengah dan Non Formal, sangat membantu untuk peningkatan kualitas layanan PAUD. Hal ini sesuai dengan tujuan BOP PAUD, yakni: 1) mendukung operasional penyelenggaraan PAU D secara efektif dan efisien, 2) pertanggungjawaban keuangan dana BO P PAU D yang dilaksanakan dengan tertib administrasi, transparan, akuntabel, tepat waktu, serta terhindar dari penyimpangan.

Setahun sekali PAU D Kenanga menyelenggarakan piknik. Seperti ditunjukkan pada Gambar 8, yang menunjukkan kegembiraan anak-anak mengikuti studi wisata ke M useum Dirgantara TNI AU Lanuma A disutjipto. Beberapa program tahunan yang telah terlaksana adalah mengunjungi Pasar Satwa dan Tanaman Hias Yogyakarta (PASTY) D ongkelan, M useum Perjuangan TN I A ngkatan U dara di D esa N goto Bantul, M useum Pusat TNI Angakatan U dara Dirgantara Mandala di Pangkalan U dara Adisutjipto, M useum Tembi Rumah Budaya, kebun binatang Gembira Loka, Taman Wisata Kyai Langgeng Magelang, dan Tirtonirmolo Water Park Galuh Klaten. Tentunya setiap penyelenggaraan program tersebut, selalu melibatkan ibu atau orang tua wali murid, karena anaka-anaka Balita masih memerlukan ibunya dalam setiap aktivitas yang dilakukannya.

Setiap akhir tahun menyelenggarakan pentas seni yang menampilkan anak-anak PAU D Kenanga untuk berani tampil dan percaya diri, dengan menampilkan gerak tari dan lagu dengan busana yang disiapkan baik oleh Ibu guru maupun orang tua wali murid yang senantiasa selalu mendampingi anak-anak. Seperti yang ditunjukkan pada Gambar 9 dan Gambar 10. 


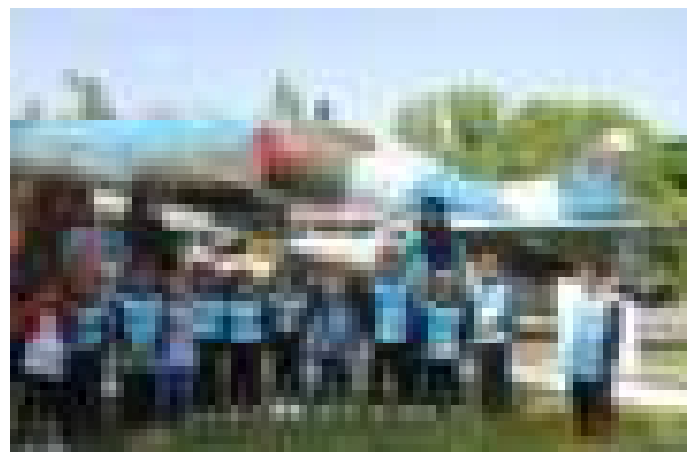

Gambar 8. Kegiatan Piknik ke Museum Dirgantara TNI AU
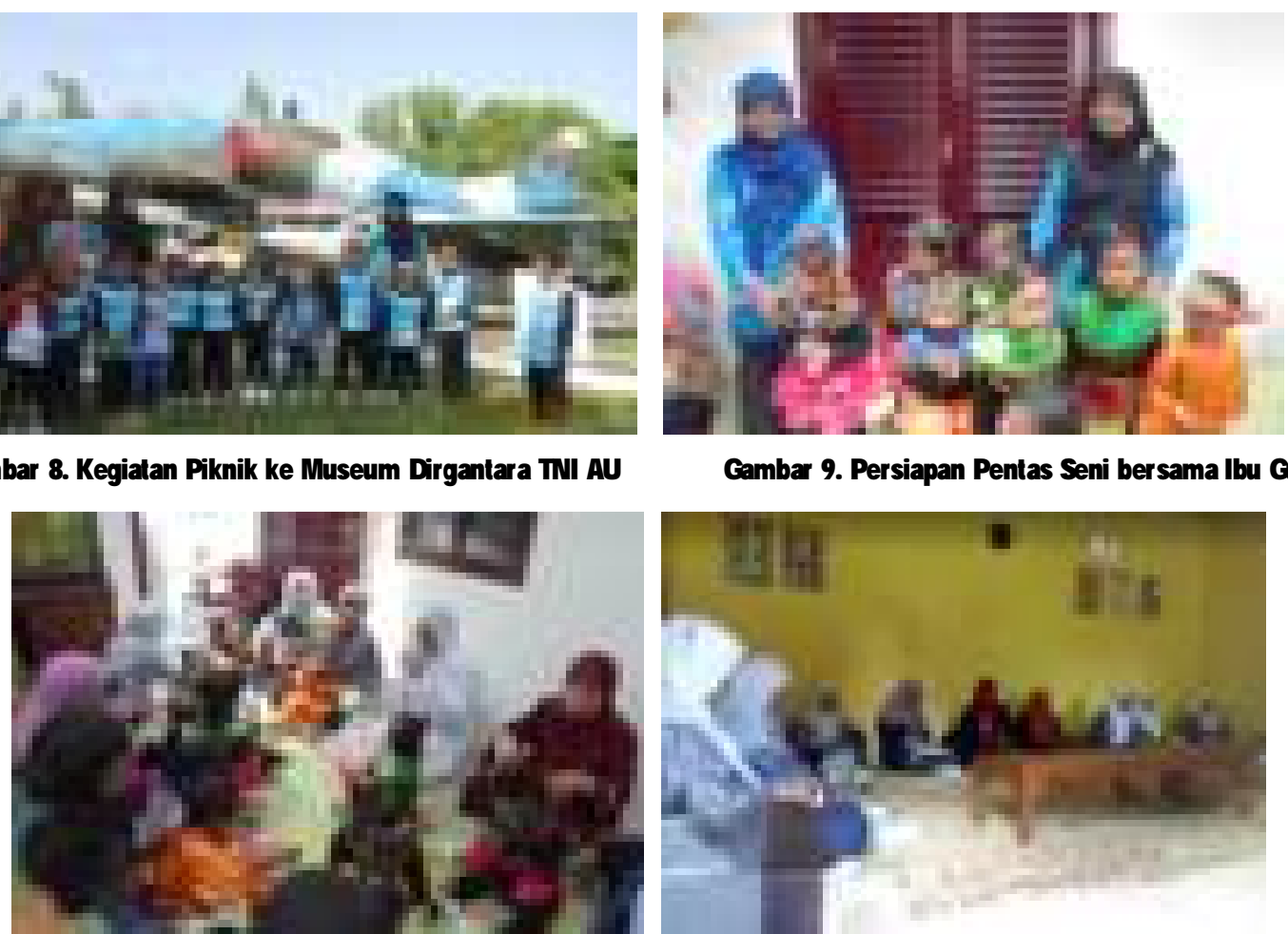

Gambar 9. Persiapan Pentas Seni bersama Ibu Guru

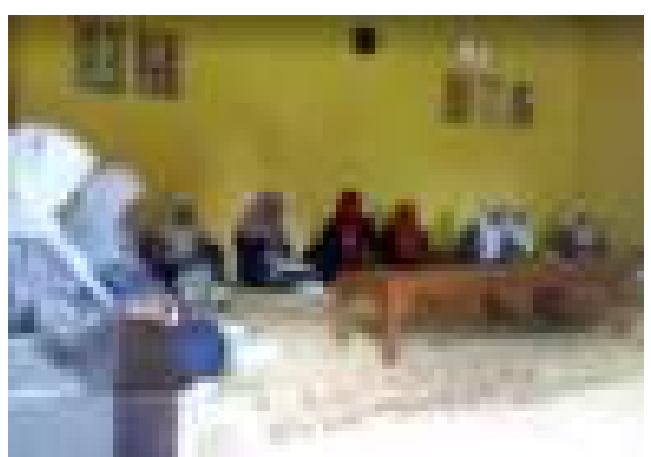

Gambar 10. Bersama Ibu dan Orang Tua Wali

Gambar 11. Rapat Gugus V PAUD Sekecamatan Sewon Bantul

U ntuk meningkatkan tatakualitas layanan dan tatakelola, para pengelola dan pendidik PAUD Kenanga secara aktif selalu berpartisipasi pada persatuan guru dan pengelola PAUD di lingkungan kecamatan Sewon Bantul, yang tercakup pada Gugus V Paud Sewon.Kegiatan ini diselen ggarakan setiap 2 bulan sekali, tempat penyelenggaraan rapat bergiliran di setiap PAU D sekecamatan Sewon, seperti diilustrasikan pada Gambar 11.

Pengupayaan sarana dan prasarana PAUD, seperti peralatan bermain dan pembangunan ruang belajar juga sudah terlaksana ( $G$ ambar 13). Tentunya pengupayaan ini adalah kerjasama dari Kepala Dukuh Glugo Panggungharjo dan ibu-ibu pengelola PAUD dan TK Budi U tami.

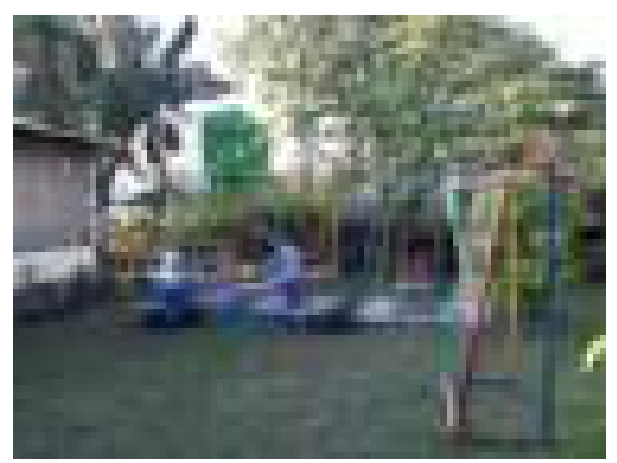

Gambar 12. Peralatan Bermain yang Baru

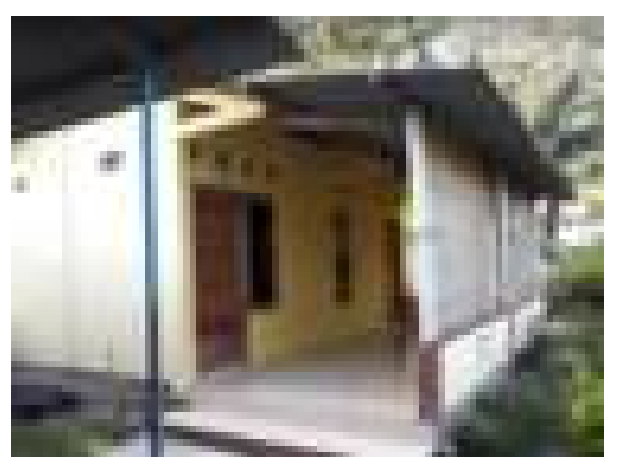

Gambar 13. Bangunan PAUD yang Baru 
Di samping itu adanya peralatan bermain yang semakin bervariasi menambah koleksi peralatan bermain untuk anak-anak PAUD, serta meningkatkan kepercayan diri anakanak untuk berani mencoba berbagai peralatan bermain ( $G$ ambar 12 ). Tentunya hal ini juga harus dengan pendampingan orang tua wali murid dan ibu guru PAU D.

\section{SIMPULAN}

Peningkatan kualitas layanan dan tata kelolaPAU D Kenanga Glugo Panggungharjo Sewon Bantul dapat berjalan sesuai dengan yang direncanakan. Dengan keterlibatan Kepala Dukuh Glugo, Ibu-ibu PKK dan ibu-ibu sukarelawan yang selalu menggiatkan program PAU D membuat penyelenggaraan PAU D di pedukuhan Glugo semakin baik. $\mathrm{H}$ al ini dibuktikan dengan bertambahnya program untuk meningkatkan kesehatan anakanak PAUD dengan penambahan makanan yang bergizi yang didanai oleh Dinas Pemberdayaan M asyarakat D esa, program piknik tahunan, sarana dan prasarana seperti pengadaan sarana bermain jungkatjungkit, ayunan, gawang sepak bola mini, komedi putar mini.

\section{UCAPAN TERIMA KASIH}

D engan terselenggaranya program peningkatan kualitas layanan dan tata kelola PAU D Kenanga, kami menghaturkan terima kasih kepada: Direktur Pembinaan PAUD, Direktorat Jenderal PAU D NI, Kementrian Pendidikan dan Kebudayaan Republik Indonesia, D inas Pemberdayaan M asyarakat D esa Panggungharjo, Kepala Pedukuhan G lugo, Ibu-ibu pengelola PKK di Pedukuhan Glugo Panggungharjo Sewon Bantul.

\section{DAFTAR PUSTAKA}

Catur Retno Wigati, "Implementasi Penguatan Kemitraan Keluarga, PAUD, dan Komite/Dewan Sekola" disampaikan pada acara Diklat Pembinaan dan Pengelola PAUD Non Formal, Dinas Pendidikan Menengah dan Non Formal Kabupaten Bantul, 2015.

Enah Suminah dkk., "Kurikulum Pendidikan Anak Usia Dini: Apa, Mengapa dan Bagaimana, Direktorat Pembinaan PAUD, 2015.

Haryati, "Aktivitas Cerdas Pengisi Kegiatan PAUD", Tugu Publisher, Jakarta, 2012.

http://www.info-dokumenpaud.com

Ika Nurul Qamari, "Dokumen PAUD Kenanga" (tidak dipublikasikan), 2009.

Seniati, "Mengkondisikan Lingkungan yang Mendukung untuk Pelaksanaan Pendidikan Nilai bagi Anak Usia Dini di TK Perkotaan dan Sekitamya" disampaikan pada acara Forum Peringatan Hari Anak Nasional, Dewan Pimpinan Daerah Gabungan Organisasi Penyelenggara Taman Kanak-Kanak Indonesia (DPD GOPTKI) DIY, Rabu 21 Agustus 2013.

Widodo, "Mengungkap Rahasia Otak Anak" disampaikan pada acara Seminar Sehari Menjadi Pendidik PAUD Lebih Profesional, Minggu 11 Desember 2011. 